This item was submitted to Loughborough's Research Repository by the author.

Items in Figshare are protected by copyright, with all rights reserved, unless otherwise indicated.

\title{
Thermal energy storage for low and medium temperature applications using phase change materials - a review
}

PLEASE CITE THE PUBLISHED VERSION

http://dx.doi.org/10.1016/j.apenergy.2016.05.097

\section{PUBLISHER}

(C) Elsevier

VERSION

AM (Accepted Manuscript)

\section{PUBLISHER STATEMENT}

This work is made available according to the conditions of the Creative Commons Attribution-NonCommercialNoDerivatives 4.0 International (CC BY-NC-ND 4.0) licence. Full details of this licence are available at: https://creativecommons.org/licenses/by-nc-nd/4.0/

\section{LICENCE}

CC BY-NC-ND 4.0

\section{REPOSITORY RECORD}

da Cunha, Jose M.P. Pinto Pereira, and Philip C. Eames. 2019. "Thermal Energy Storage for Low and Medium Temperature Applications Using Phase Change Materials - a Review”. figshare. https://hdl.handle.net/2134/21639. 


\section{TURE APPLICATIONS USING PHASE CHANGE MATERIALS}

\section{- A REVIEW}

Jose Pereira da Cunha, j.pereira-da-cunha@lboro.ac.uk, Centre for Renewable Energy Systems Technology (CREST); Loughborough University, Loughborough (Leicestershire) LE11 3TU, United Kingdom;

Philip Eames, p.c.eames@lboro.ac.uk, Centre for Renewable Energy Systems Technology (CREST); Loughborough University, Loughborough (Leicestershire) LE11 3TU, United Kingdom;

A comprehensive review of phase change materials (PCMs) with phase transition temperatures between 0 and $250{ }^{\circ} \mathrm{C}$ is presented. From that review, organic compounds and salt hydrates seem more promising below $100{ }^{\circ} \mathrm{C}$ and eutectic mixtures from 100 to $250{ }^{\circ} \mathrm{C}$.

Practical indirect heat exchanger designs for latent heat storage systems were also assessed and feasible heat enhancement mechanisms reviewed. The focus on this temperature range is due to potential CO2 emissions reduction able to be achieved replacing conventional heating and cooling applications in the domestic, commercial and public administration sectors, which represented around a quarter of the UK's final energy consumption in 2015.

Keywords:

Phase change materials, Thermal Energy storage, Inorganic PCMs, Organic PCMs, Eutectic PCMs, Latent Heat Storage.

\section{INTRODUCTION}

To date, the measures adopted to stabilize global temperature rise below the $2^{\circ} \mathrm{C}$ target, are likely to be insufficient [1]. If this target is to be achieved, there must be an increased effort to de-carbonize global energy consumption, which still relies heavily on fossil fuel sources.

Conventional heating and cooling in the domestic, commercial and public administration sectors had a combined natural gas and petroleum products consumption of around $25 \%$ of the UK's final energy consumption in 2014 [2]. The distribution per sector is presented in Figure 1.

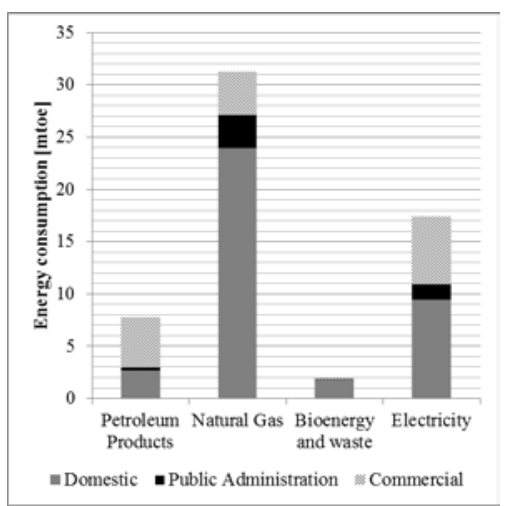

Figure 1- The UK's final energy consumption aggregated values for 2014 [2] by source in the Domestic, Commercial and Public Administration sectors. 
To reduce the $\mathrm{CO} 2$ emissions in the domestic heating sector, heat pumps could be used as an alternative to current fossil fuel burning systems; however, their usage should the restricted to off peak times (between 22.00 and 07.00), in order not to greatly increase the UK's electrical grid peak demand [3], Figure 2, with local heat storage being used to meet heat demand at other times. .

The daily variation of CO2 emissions per kWh of electricity consumed for the $15^{\text {th }}$ of January and July of 2015 are presented in Figure 2, values were obtained for the generation mix for the UK national grid and $\mathrm{CO} 2$ emission factors applied similar to those estimated by Hawkes et al [4]. In order to match the $\mathrm{CO} 2$ emissions associated with grid electricity to natural gas used for space heating (204.9 gCO2/kWh [2]), the minimum coefficient of performance (COP) required for heat pumps is approximately 2.

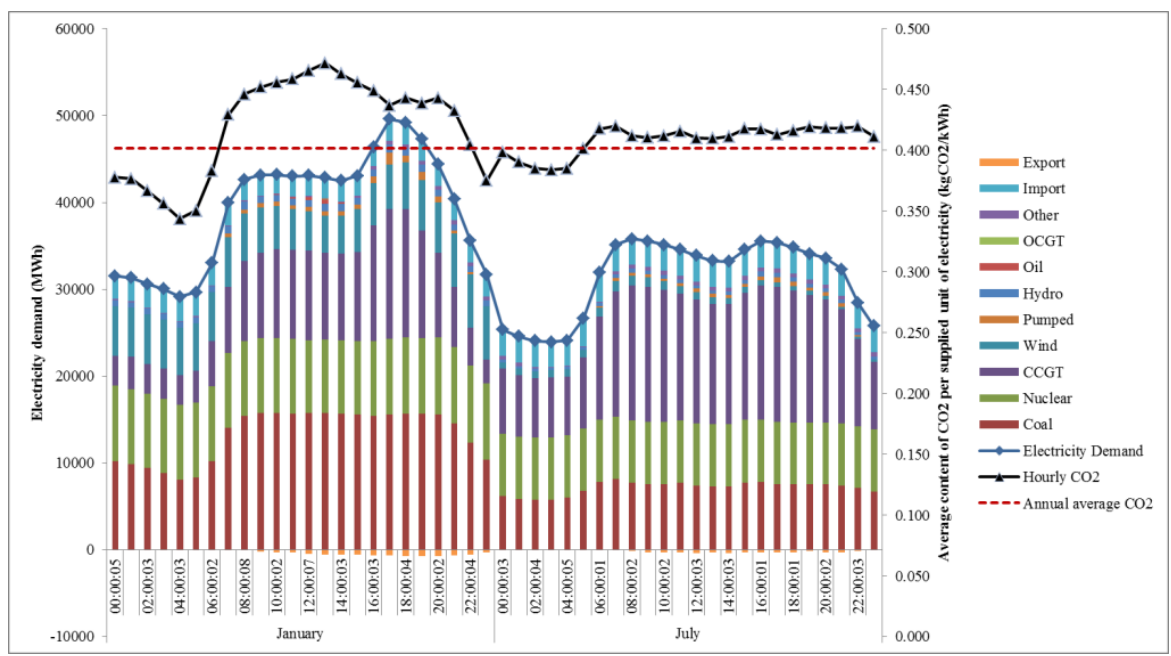

Figure 2 - Seasonal and hourly variation of $\mathrm{CO}_{2}$ emissions associated with the electricity supplied by the UK national grid - sample date:15/01/2015 \& 15/07/2015[4], [5].

The use of solar thermal systems is another potential way of reducing $\mathrm{CO}_{2}$ emissions associated with space and water heating, effective thermal energy storage will be essential to address the mismatch between the intermittent solar heat supply and the heat demand. [6], [7].

Thermal energy storage can be achieved through 3 distinct ways: sensible; latent or thermochemical heat storage. Sensible heat storage relies on the material's specific heat capacity. Latent heat storage relies on the material's phase change enthalpy to store heat within a narrow temperature range, providing greater energy density $\left[\mathrm{kWh}_{\mathrm{t}} / \mathrm{m}^{3}\right]$ than that achievable with sensible heat storage over the same temperature gradient; however, volumetric expansions during the melting process can reach 10 to $15 \%$ for some materials. Thermochemical heat storage is more energetic than latent heat storage, but since it relies on adsorption / desorption or other chemical reactions, reaction kinetics and reactor design significantly determine their actual performance, and require distinct charging and discharging temperatures [8] (usually between 100 and $300{ }^{\circ} \mathrm{C}$, depending on the reaction), having potential interest for interseasonal storage applications. Figure 3 A shows, heat storage capacity $\left[\mathrm{kWh}_{\mathrm{th}} / \mathrm{m}^{3}\right]$ of water sensible heat storage and 3 PCMs over a $20{ }^{\circ} \mathrm{C}$ temperature interval; the PCMs store around 2.5 to 6 times more energy than water.. Figure $3 \mathrm{~B}$ compares thermochemical heat storage to a packed rock bed heat storage system; the hydration of the thermochemical compound can theoretically release 25 times more energy than what achievable with $40^{\circ} \mathrm{C}$ of air temperature increase in a rock bed heat storage system, although temperatures up to $120^{\circ} \mathrm{C}$ are required for dehydration of the salt hydrate ; such thermochemical heat storage materials may prove to be suitable candidates for inter seasonal thermal energy storage. 


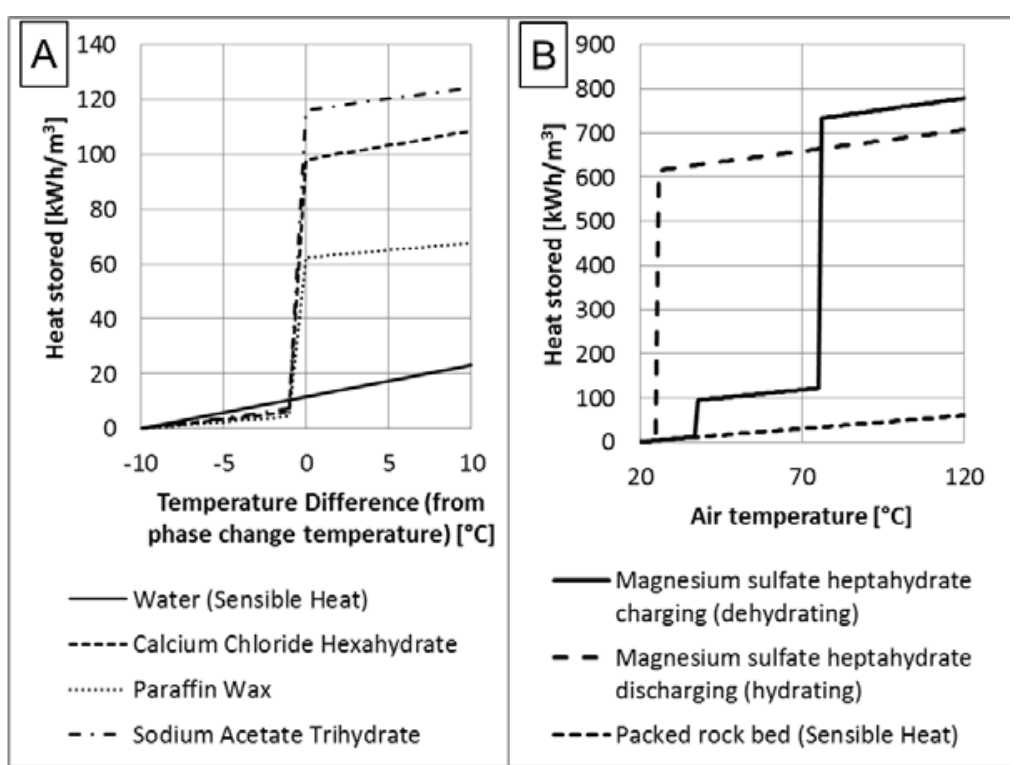

Figure 3- Heat stored vs. Temperature diagrams for 3 PCMs and a sensible water heat storage system (A) and magnesium sulphate heptahydrate (data retrieved from Zondag et al. [8]) compared to a conventional rock bed storage system (B).

Medium and large scale systems such as centralized cooling (absorption chillers [9], [10], [11]) and district heating networks [12]-[13], used commonly in hospitals, commercial centres and office buildings could also benefit from latent heat storage systems, when supplied by solar thermal collectors.

Another potential application for latent heat storage would be integration into solar thermal driven organic rankine cycles (ORC) [14]. The characterization of a compact ORC system for low grade transient solar energy conversion was made by [15], and it was concluded that adding latent heat thermal energy storage could potentially stabilize the system to short term weather irregularities (clouds, fog, etc) or even depending on the storage size, be able to maintain daily production.

Latent heat energy storage may also have use in industry when integrated in some thermal batch processes, potentially reducing sensible heat losses in the heating and cooling process necessary to achieve optimum process temperatures [9], and allowing heat to be stored between cycles. Such batch processes can be found in most of the food and beverages industry (beer, milk, chocolate, cheese, coffee, canned food) and industrial drying processes. The possible integration of solar thermal collectors into some common industrial applications in Cyprus was presented by Kalogirou [16].

For nominal operation of latent heat storage systems, the PCM must have a relative high latent heat of fusion, stability in its molten state and be chemically inert with its enclosure. Another important requirement would be a low degree of subcooling; else their enhanced heat capacity won't be fully realised . One of the main properties of commonly used PCMs is their low thermal conductivity, usually between 0.2 and 0.7 [W/m.K], requiring the use of complex heat exchanger geometries to obtain required heat transfer rates from latent heat storage containers. Conventional techniques to overcome the low heat transfer characteristic rates would be the used of metal fins [17]; however novel promising techniques such as carbon cloths [18], shape stabilized PCMs with graphite [19], [20] microencapsulated-PCM slurries [21] and direct contact latent heat storage systems [22], [23] can also be used to increase the global UA value of latent heat storage systems.

\section{Phase Change Materials Literature ReVieW}

In order to assess the potential of latent heat storage applications, a comprehensive review of the PCMs physical properties during phase change is critical. For a comparative economic evaluation, market prices for industrial grade materials were used to provide a common approach. 


\section{i. ORgANIC PCMs}

Organic compounds, characterized by having carbon atoms in their structure, generally have very low thermal conductivity (from 0.1 to $0.7 \mathrm{~W} / \mathrm{m} . \mathrm{K}$ ), hence requiring mechanisms to enhance their heat transfer in order to achieve reasonable rates of heat output (W). Table 1 presents the thermophysical properties of the compounds identified for further analysis based on their relative low price, their quoted stability from the review and enthalpy of phase change. The Organic compounds reviewed that appeared to be promising in this temperature range are some of the saturated fatty acids [24]; sugar alcohols [25], [26], carboxylic acids [27], amides [28] and alkanes [29]. Urea [30], is not a promising compound in its pure state, due to its instability when molten [31], but some of its eutectic mixtures seem to have suitable properties for latent heat storage, with details presented in Table 3.

Table 1 - Thermophysical properties of selected organic compounds

\begin{tabular}{|c|c|c|c|c|c|c|c|c|c|c|c|c|}
\hline \multirow{3}{*}{$\begin{array}{l}\text { Compound } \\
\text { Formic Acid } \\
\end{array}$} & \multirow{3}{*}{$\begin{array}{c}\mathbf{T}_{\mathbf{m}} \\
{ }^{\circ} \mathbf{C} \\
8 \\
\end{array}$} & \multirow{3}{*}{\begin{tabular}{r|}
$\frac{\Delta \mathbf{H}_{\mathbf{m}}}{\mathbf{k J} / \mathbf{k g}}$ \\
277 \\
\end{tabular}} & $C p_{s}$ & $C p_{1}$ & $\lambda_{\mathrm{s}}$ & $\lambda_{1}$ & \multirow{3}{*}{$\begin{array}{c}\frac{\rho_{\mathrm{s}}}{\mathbf{k g} / \mathbf{m}^{3}} \\
1227 \\
\end{array}$} & \multirow{3}{*}{$\begin{array}{c}\frac{V_{\text {exp }}}{\mathbf{m}^{3} / \mathbf{m}^{3}} \\
12.0 \\
\end{array}$} & \multirow{3}{*}{$\begin{array}{c}\mathbf{E}_{\text {density }} \\
\mathbf{k W h} / \mathbf{m}^{\mathbf{3}} \\
96 \\
\end{array}$} & \multicolumn{2}{|c|}{ Price } & \multirow{3}{*}{$\begin{array}{c}\text { Ref. } \\
\text { [32], [33] }\end{array}$} \\
\hline & & & \multicolumn{2}{|c|}{ kJ/kg.K } & \multicolumn{2}{|c|}{ W/m.K } & & & & $£ / \mathbf{m}^{3}$ & E/kWh & \\
\hline & & & 1.00 & 1.17 & 0.30 & 0.27 & & & & 255 & 4.2 & \\
\hline Acetic Acid & 17 & 192 & 1.33 & 2.04 & 0.26 & 0.19 & 1214 & 13.5 & 71 & 327 & 7.2 & [32], [34] \\
\hline Lauric acid & 44 & 212 & 2.02 & 2.15 & 0.22 & 0.15 & 1007 & 13.6 & 66 & 276 & 6.5 & [32], [34] \\
\hline Stearic acid & 54 & 157 & 1.76 & 2.27 & 0.29 & 0.17 & 940 & 9.9 & 49 & 345 & 11.0 & $\begin{array}{c}{[31],} \\
{[33],} \\
{[35],[36]}\end{array}$ \\
\hline Palmitic acid & 61 & 222 & 1.69 & 2.20 & 0.21 & 0.17 & 989 & 14.1 & 67 & 354 & 8.3 & $\begin{array}{c}{[32],} \\
{[35],} \\
{[37],[38]}\end{array}$ \\
\hline Paraffin Wax & $0-90$ & $\begin{array}{l}150 \\
- \\
250 \\
\end{array}$ & 3.00 & 2.00 & \multicolumn{2}{|c|}{0.2} & $\begin{array}{c}880 \\
- \\
950 \\
\end{array}$ & $\begin{array}{c}12 \\
- \\
14 \\
\end{array}$ & $\begin{array}{c}50 \\
- \\
70 \\
\end{array}$ & $\begin{array}{c}400 \\
- \\
500 \\
\end{array}$ & $\begin{array}{c}9.5 \\
- \\
7.1\end{array}$ & $\begin{array}{c}\text { [9], [32], } \\
\text { [39] }\end{array}$ \\
\hline Acetamide & 82 & 260 & 2.00 & 3.00 & 0.40 & 0.25 & 1160 & 13.9 & 93 & 1318 & 22.2 & [32], [40] \\
\hline Oxalic acid & 105 & 356 & 1.62 & 2.73 & & & 1900 & & 211 & 524 & 3.9 & [27], [41] \\
\hline Erythritol & 117 & 340 & 2.25 & 2.61 & 0.73 & 0.33 & 1450 & 10.3 & 148 & 1287 & 13.6 & $\begin{array}{c}25], \\
{[31],[42]}\end{array}$ \\
\hline HDPE & 130 & 255 & 2.60 & 2.15 & 0.48 & 0.44 & 952 & & 80 & 463 & 9.0 & [32], [43] \\
\hline $\begin{array}{c}\text { Phthalic an- } \\
\text { hydride }\end{array}$ & 131 & 160 & 1.85 & 2.20 & & & 1530 & & 85 & 2042 & 37.4 & [44] \\
\hline Urea & 134 & 250 & 1.80 & 2.11 & 0.80 & 0.60 & 1320 & 16.7 & 97 & 189 & 3.0 & $\begin{array}{c}{[30],} \\
{[31],[45]}\end{array}$ \\
\hline Maleic acid & 141 & 385 & 1.17 & 2.08 & & & 1590 & & 184 & 1059 & 9.0 & $\begin{array}{c}{[31],} \\
{[46],[47]}\end{array}$ \\
\hline $\begin{array}{c}2- \\
\text { Chlorobenzoic } \\
\text { acid } \\
\end{array}$ & 142 & 164 & 1.30 & 1.60 & & & 1544 & & 83 & 1861 & 35.1 & [48] \\
\hline Adipic acid & 152 & 275 & 1.87 & 2.72 & & & 1360 & 20.2 & 109 & 584 & 8.4 & [49] \\
\hline d-Mannitol & 165 & 300 & 1.31 & 2.36 & 0.19 & 0.11 & 1490 & & 139 & 1027 & 11.5 & $\begin{array}{c}{[25],} \\
{[50]-[52]}\end{array}$ \\
\hline Hydroquinone & 172 & 258 & 1.59 & 1.64 & & & 1300 & & 105 & 3415 & 50.9 & [32], [53] \\
\hline
\end{tabular}

\section{ii. SALT HYDRATES}

Salt hydrates, formed by water absorption by the anhydrous salt at ambient temperatures, have a phase change enthalpy depending on the bond strength between the water molecules and the salt. Super cooling during crystallization [54], phase segregation [55] and corrosion with commonly used metals (copper, aluminium, stainless steel) [56], are the main issues inhibiting their use in latent heat energy storage systems. Table 2 presents the thermophysical properties for a selection of salt hydrates. 
Table 2 - Thermophysical properties of selected salt hydrates;

\begin{tabular}{|c|c|c|c|c|c|c|c|c|c|c|c|c|}
\hline \multirow{2}{*}{ Compound } & \multirow{2}{*}{$\begin{array}{l}\mathbf{T}_{\mathbf{m}} \\
{ }^{\circ} \mathbf{C}\end{array}$} & \multirow{2}{*}{$\begin{array}{c}\Delta \mathbf{H}_{\mathrm{m}} \\
\mathrm{kJ} / \mathrm{kg}\end{array}$} & $C \mathbf{p}_{\mathrm{s}}$ & $\mathbf{C p}_{\mathbf{1}}$ & $\lambda_{s}$ & $\lambda_{1}$ & \multirow{2}{*}{$\frac{\rho_{\mathrm{s}}}{\mathrm{kg} / \mathrm{m}^{3}}$} & \multirow{2}{*}{$\frac{V_{\text {exp }}}{\mathbf{m}^{3} / \mathbf{m}^{3}}$} & \multirow{2}{*}{$\frac{E_{\text {density }}}{\mathbf{k W h} / \mathbf{m}^{3}}$} & \multicolumn{2}{|c|}{ Price } & \multirow{2}{*}{ Ref. } \\
\hline & & & \multicolumn{2}{|c|}{ kJ/kg.K } & \multicolumn{2}{|c|}{ W/m.K } & & & & $\mathfrak{E} / \mathbf{m}^{3}$ & $\varepsilon / k W h$ & \\
\hline Water & 0 & 333 & 3.30 & 4.18 & 1.60 & 0.61 & 920 & -8.7 & 109 & 0 & 0.0 & [32], [57] \\
\hline $\begin{array}{c}\text { Calcium Chloride } \\
\text { Hexahydrate }\end{array}$ & 30 & 125 & 1.42 & 2.20 & 1.09 & 0.53 & 1710 & 11 & 64 & 93 & 2 & $\begin{array}{l}\text { [9], [32], } \\
{[56],[58]}\end{array}$ \\
\hline $\begin{array}{l}\text { Sodium Sulphate } \\
\text { Decahydrate }\end{array}$ & 32 & 180 & 1.93 & 2.80 & 0.56 & 0.45 & 1485 & 4 & 82 & 48 & 1 & $\begin{array}{c}9],[32], \\
{[56]}\end{array}$ \\
\hline $\begin{array}{l}\text { Sodium Thiosulfate } \\
\text { Pentahydrate }\end{array}$ & 46 & 210 & 1.46 & 2.39 & 0.76 & 0.38 & 1666 & 6 & 103 & 199 & 3 & $\begin{array}{c}\text { [32], [43], } \\
{[59]}\end{array}$ \\
\hline $\begin{array}{l}\text { Sodium Acetate } \\
\text { Trihydrate }\end{array}$ & 58 & 266 & 1.68 & 2.37 & 0.43 & 0.34 & 1450 & 3 & 113 & 233 & 3 & $\begin{array}{c}\text { [32], [60], } \\
{[61]}\end{array}$ \\
\hline $\begin{array}{l}\text { Barium Hydroxide } \\
\text { Octahydrate }\end{array}$ & 78 & 280 & 1.34 & 2.44 & 1.26 & 0.66 & 2180 & 11 & 171 & 422 & 4 & $\begin{array}{c}\text { [32], [62], } \\
{[63]}\end{array}$ \\
\hline $\begin{array}{l}\text { Magnesium Nitrate } \\
\text { Hexahydrate }\end{array}$ & 89 & 140 & 2.50 & 3.10 & 0.65 & 0.50 & 1640 & 5 & 74 & 131 & 3 & $\begin{array}{c}\text { [9], [32], } \\
\text { [54] }\end{array}$ \\
\hline $\begin{array}{c}\text { Oxalic acid Dihy- } \\
\text { drate }\end{array}$ & 105 & 264 & 2.11 & 2.89 & 0.90 & 0.70 & 1653 & 0 & 133 & 339 & 4 & [31], [41] \\
\hline $\begin{array}{l}\text { Magnesium Chlo- } \\
\text { ride Hexahydrate }\end{array}$ & 117 & 150 & 2.00 & 2.40 & 0.70 & 0.58 & 1570 & 8 & 72 & 56 & 1 & $\begin{array}{c}\text { [32], [54], } \\
{[64]}\end{array}$ \\
\hline
\end{tabular}

131

\section{a. PHASE SEPARATION}

Water separation, related to poor molecular bonding [55], [64] is the main factor determining thermal stability in the molten phase. Suitable encapsulation could help reduce the effects of water segregation, since it would prevent the release of partially evaporated water.

\section{b. SUPER COOLING}

The onset of solidification can occur at a significantly lower temperature than the melting point, normally around 10 to $20^{\circ} \mathrm{C}$ [37]. Adding other salts with similar crystal structures, increases nucleation points, and may reduce this phenomenon. A study of Magnesium chloride hexahydrate [64], proved that the addition of Strontium Carbonate, Strontium Hydroxide and Magnesium Hydroxide effectively reduced super cooling for this salt.

\section{iii. EUTECTIC PCMs}

Binary and ternary mixtures of inorganic salts have been widely studied for thermal storage applications. Nitrate, chloride and sulphate salts of alkali and alkaline metals, such as magnesium, potassium, lithium and calcium, are the main compounds used to produce medium temperature eutectic mixtures, also known as ionic liquids [65].

Due to their higher density and stability in their liquid state, they have been used widely as ionic liquids in high temperature sensible thermal storage systems (thermonuclear energy, concentrated solar thermal power [66]-[68]).

Due to the lack of experimental data for some of the thermophysical properties of eutectic mixtures, weighting methods have been used to predict missing values [69], [70]. More developed techniques to predict thermophysical properties of eutectic mixtures do exist [71], [72], involving Van Der Waals volumes and surface areas of stable molecular combinations; however, more simplified correlations were used. The weighting correlations used to obtain the thermophysical properties, namely heat capacity $(\mathrm{Cp})$, density $(\rho)$, thermal conductivity $(\lambda)$ and melting enthalpy $\left(\Delta \mathrm{H}_{\mathrm{m}}\right)$, are presented in equations 1 to 6 , which use available properties of the mixture and its constituents, molar ratio $\left(\mathrm{x}_{\mathrm{i}}\right)$, mass ratio $\left(\mathrm{w}_{\mathrm{i}}\right)$ and volumetric ratio $\left(\mathrm{z}_{\mathrm{i}}\right)$ and their melting point $(\mathrm{Tm})$ to predict the unknown values. A comparison was made with some eutectic salts for which experimental data was available; the difference between predictions and measurements was less than $10 \%$. Table 3 presents the physical proper- 
ties of the selected eutectic compounds in the $0-250{ }^{\circ} \mathrm{C}$ range, with the predicted latent heat values shown in bold.

$$
\begin{gathered}
w_{i}=x_{i} \times M_{i} \times\left(\sum_{i} x_{i} \times M_{i}\right)^{-1} \\
z_{i}=\frac{w_{i}}{\rho_{i}} \times\left(\sum_{i} \frac{w_{i}}{\rho_{i}}\right)^{-1} \\
C p_{\text {eutectic }}=\sum_{i} C p_{i} \times w_{i} \\
\rho_{\text {eutectic }}=\sum_{i} \rho_{i} \times z_{i} \\
\lambda_{\text {eutectic }}=\prod_{i} \lambda_{i}^{z_{i}} \\
\Delta H_{\text {eutectic }}=\text { Tm }_{\text {eutectic }} \times \sum_{i} \frac{\Delta H_{i} \times w_{i}}{T m_{i}}
\end{gathered}
$$

\begin{tabular}{|c|c|c|c|c|c|c|c|c|c|c|c|c|}
\hline \multirow{3}{*}{$\begin{array}{c}\begin{array}{c}\text { Eutectic } \\
\text { Compounds }\end{array} \\
\mathrm{CaCl}_{2} \cdot\left(\mathrm{H}_{2} \mathrm{O}\right)_{6} \\
- \\
\mathrm{MgCl}_{2} \cdot\left(\mathrm{H}_{2} \mathrm{O}\right)_{6} \\
\end{array}$} & \multirow{3}{*}{$\begin{array}{l}\text { Mass } \\
\text { Ratio } \\
67-33\end{array}$} & \multirow{3}{*}{$\begin{array}{l}\mathbf{T}_{\mathbf{m}} \\
{ }^{\circ} \mathbf{C} \\
25\end{array}$} & \multirow{3}{*}{$\begin{array}{r}\frac{\Delta \mathbf{H}_{\mathrm{m}}}{\mathrm{kJ} / \mathrm{kg}} \\
127\end{array}$} & $\mathbf{C} \mathbf{p}_{\mathrm{s}}$ & $\mathbf{C} \mathbf{p}_{1}$ & $\lambda_{\mathrm{s}}$ & $\lambda_{1}$ & \multirow{3}{*}{\begin{tabular}{|l}
$\frac{\rho_{\mathrm{s}}}{\mathrm{kg} / \mathbf{m}^{3}}$ \\
1661
\end{tabular}} & \multirow{3}{*}{$\begin{array}{c}\frac{\mathbf{E}_{\text {density }}}{\mathbf{k W h} / \mathbf{m}^{3}} \\
57\end{array}$} & \multicolumn{2}{|c|}{ Price } & \multirow{3}{*}{$\begin{array}{l}\text { Ref } \\
{[32]} \\
{[43]} \\
\end{array}$} \\
\hline & & & & \multicolumn{2}{|c|}{ J/kg.K } & \multicolumn{2}{|c|}{$\mathbf{m W} / \mathbf{m} \cdot \mathbf{K}$} & & & $\mathrm{E} / \mathrm{m}^{3}$ & E/kWh & \\
\hline & & & & 1620 & 2270 & 930 & 550 & & & 80 & 1.4 & \\
\hline $\begin{array}{c}\text { Urea } \\
- \\
\mathrm{CH}_{3} \mathrm{COONa} .\left(\mathrm{H}_{2} \mathrm{O}\right)_{3}\end{array}$ & $60-40$ & 30 & 200 & 1750 & 2210 & 630 & 480 & 1370 & 74 & 206 & 2.8 & $\begin{array}{c}{[43],} \\
{[73]}\end{array}$ \\
\hline $\begin{array}{c}\mathrm{Mg}\left(\mathrm{NO}_{3}\right)_{2} \cdot\left(\mathrm{H}_{2} \mathrm{O}\right)_{6} \\
- \\
\mathrm{NH}_{4} \mathrm{NO}_{3} \\
\end{array}$ & $61-39$ & 52 & 125 & 2130 & 2670 & 590 & 500 & 1672 & 58 & 188 & 3.3 & $\begin{array}{c}{[43],} \\
{[73]}\end{array}$ \\
\hline Urea - Acetamide & $38-62$ & 53 & 224 & 1920 & 2660 & 510 & 340 & 1216 & 73 & 924 & 13 & [58] \\
\hline $\begin{array}{c}\text { Stearic Acid } \\
- \\
\text { Palmitic Acid }\end{array}$ & $36-64$ & 53 & 182 & 1720 & 2230 & 234 & 169 & 971 & 46 & 351 & 8 & [74] \\
\hline $\begin{array}{c}\mathrm{Mg}\left(\mathrm{NO}_{3}\right)_{2} \cdot\left(\mathrm{H}_{2} \mathrm{O}\right)_{6} \\
- \\
\mathrm{MgCl}_{2} \cdot\left(\mathrm{H}_{2} \mathrm{O}\right)_{6}\end{array}$ & $59-41$ & 59 & 132 & 2290 & 2810 & 670 & 530 & 1610 & 58 & 99 & 1.7 & \\
\hline $\begin{array}{c}\text { Stearic Acid } \\
- \\
\text { Acetamide } \\
\end{array}$ & $83-17$ & 65 & 213 & 1800 & 2400 & 300 & 180 & 972 & 56 & 485 & 8.6 & $\begin{array}{c}{[32],} \\
{[43]}\end{array}$ \\
\hline $\begin{array}{c}\mathrm{LiNO}_{3} \\
- \\
\mathrm{MgNO}_{3} \cdot\left(\mathrm{H}_{2} \mathrm{O}\right)_{6} \\
\end{array}$ & $14-86$ & 72 & 180 & 2380 & 2900 & 700 & 510 & 1713 & 84 & 718 & 8.5 & \\
\hline Urea - $\mathrm{LiNO}_{3}$ & $82-18$ & 76 & 218 & 1770 & 2020 & 850 & 600 & 1438 & 84 & 851 & 10.1 & \\
\hline Urea - $\mathrm{NaNO}_{3}$ & $71-29$ & 83 & 187 & 1600 & 2030 & 750 & 590 & 1502 & 76 & 220 & 2.9 & \\
\hline Urea - $\mathrm{NH}_{4} \mathrm{Cl}$ & $85-15$ & 102 & 214 & 1770 & 2090 & 760 & 580 & 1348 & 77 & 174 & 2.3 & \\
\hline Urea $-\mathrm{K}_{2} \mathrm{CO}_{3}$ & $15-85$ & 102 & 206 & 1660 & 2020 & 780 & 580 & 1415 & 78 & 269 & 3.4 & [/3] \\
\hline Urea - $\mathrm{KNO}_{3}$ & $77-23$ & 109 & 195 & 1600 & 1910 & 810 & 580 & 1416 & 74 & 255 & 3.4 & \\
\hline Urea - NaCl & $90-10$ & 112 & 230 & 1720 & 2020 & 820 & 600 & 1372 & 85 & 180 & 2.1 & \\
\hline
\end{tabular}

Table 3 - Thermophysical properties of selected eutectic compounds 


\begin{tabular}{|c|c|c|c|c|c|c|c|c|c|c|c|c|}
\hline Urea - KCl & $89-11$ & 115 & 227 & 1690 & 1960 & 830 & 0.60 & 1370 & 83 & 197 & 2.4 & \\
\hline $\begin{array}{c}\mathrm{LiNO}_{3}-\mathrm{NaNO}_{3}- \\
\mathrm{KNO}_{3} \\
\end{array}$ & $\begin{array}{c}30-18- \\
52 \\
\end{array}$ & 123 & 140 & 1170 & 1440 & 790 & 530 & 2068 & 79 & 1979 & 25 & $\begin{array}{c}{[75],} \\
{[76]}\end{array}$ \\
\hline $\mathrm{LiNO}_{3}-\mathrm{KNO}_{3}$ & $34-66$ & 133 & 150 & 1170 & 1350 & 960 & 520 & 2018 & 82 & 2167 & 26 & $\begin{array}{c}{[75]-} \\
{[77]}\end{array}$ \\
\hline $\mathrm{KNO}_{3}-\mathrm{NaNO}_{2}$ & $56-44$ & 141 & 97 & 1180 & 1740 & 730 & 570 & 1994 & 52 & 504 & 9.7 & $\begin{array}{c}78, \\
\text { p. } \\
778]\end{array}$ \\
\hline $\begin{array}{c}\mathrm{KNO}_{3}-\mathrm{NaNO}_{3}- \\
\mathrm{NaNO}_{2}\end{array}$ & $\begin{array}{c}53-6- \\
41\end{array}$ & 142 & 110 & 1170 & 1730 & 720 & 570 & 2006 & 60 & 497 & 8.3 & $\begin{array}{c}{[32],} \\
{[78,} \\
\text { p. } \\
786]\end{array}$ \\
\hline $\mathrm{KNO}_{2}-\mathrm{NaNO}_{3}$ & 48-52 & 149 & 124 & 1050 & 1630 & 580 & 520 & 2080 & 70 & 994 & 14 & \multirow{2}{*}{ [78] } \\
\hline $\mathrm{LiNO}_{3}-\mathrm{NaNO}_{2}$ & $62-38$ & 156 & 233 & 1570 & 1910 & 1120 & 660 & 2296 & 143 & 3816 & 27 & \\
\hline $\mathrm{LiNO}_{3}-\mathrm{KCl}$ & $58-42$ & 160 & 272 & 1260 & 1350 & 1310 & 590 & 2196 & 161 & 3409 & 21 & \multirow{2}{*}{$\begin{array}{l}{[32],} \\
{[79]}\end{array}$} \\
\hline $\begin{array}{c}\mathrm{LiNO}_{3}-\mathrm{NaNO}_{3}- \\
\mathrm{KCl}\end{array}$ & $\begin{array}{c}45-50- \\
5\end{array}$ & 160 & 266 & 1320 & 1690 & $\mathbf{8 8 0}$ & 590 & 2297 & 166 & 2852 & 17 & \\
\hline $\begin{array}{c}\text { HCOONa - } \\
\text { HCOOK }\end{array}$ & $45-55$ & 176 & 175 & 1150 & 930 & 630 & 430 & 1913 & 92 & 421 & 4.6 & [80] \\
\hline $\mathrm{LiOH}-\mathrm{LiNO}_{3}$ & $19-81$ & 183 & 352 & 1600 & 2000 & 1330 & 690 & 2124 & 202 & 5165 & 26 & [78] \\
\hline $\mathrm{LiNO}_{3}-\mathrm{NaNO}_{3}$ & $49-51$ & 194 & 262 & 1350 & 1720 & 870 & 590 & 2317 & 165 & 3084 & 19 & $\begin{array}{l}{[32],} \\
{[78]}\end{array}$ \\
\hline $\mathrm{LiNO}_{3}-\mathrm{NaCl}$ & $87-13$ & 208 & 369 & 1540 & 1560 & 1350 & 630 & 2350 & 235 & 5254 & 22 & $\begin{array}{l}{[32],} \\
{[79],} \\
{[81]}\end{array}$ \\
\hline $\mathrm{KNO}_{3}-\mathrm{KOH}$ & $80-20$ & 214 & 83 & 1030 & 1350 & 880 & 540 & 1905 & 43 & 611 & 14 & \multirow{2}{*}{ [32] } \\
\hline $\mathrm{KNO}_{3}-\mathrm{NaNO}_{3}$ & $55-45$ & 222 & 110 & 1010 & 1490 & 730 & 510 & 2028 & 61 & 482 & 8.0 & \\
\hline $\mathrm{LiBr}-\mathrm{LiNO}_{3}$ & $27-73$ & 228 & 279 & 1340 & 1380 & 1140 & 570 & 2603 & 196 & 6134 & 31 & \multirow{5}{*}{$\begin{array}{l}{[78]} \\
{[82]}\end{array}$} \\
\hline $\begin{array}{c}\mathrm{LiOH}-\mathrm{NaNO}_{3}- \\
\mathrm{NaOH}\end{array}$ & $\begin{array}{c}6-67- \\
27\end{array}$ & 230 & 184 & 1300 & 2000 & 780 & 670 & 2154 & 107 & 538 & 5.0 & \\
\hline $\mathrm{NaNO}_{2}-\mathrm{NaNO}_{3}$ & $55-45$ & 233 & 163 & 1310 & 2130 & 590 & 640 & 2210 & 97 & 382 & 3.9 & \\
\hline $\mathrm{CaCl}_{2}-\mathrm{LiNO}_{3}$ & $13-87$ & 238 & 317 & 1500 & 1530 & 1370 & 690 & 2362 & 204 & 5325 & 26 & \\
\hline $\mathrm{LiCl}-\mathrm{LiNO}_{3}$ & 9-91 & 244 & 342 & 1580 & 1610 & 1370 & 640 & 2351 & 218 & 6019 & 28 & \\
\hline $\mathrm{NaNO}_{3}-\mathrm{NaOH}$ & $86-14$ & 250 & 160 & 1190 & 1860 & 660 & 600 & 2241 & 97 & 339 & 3.5 & [32] \\
\hline
\end{tabular}

\section{POTENTIAL APPLiCATIONS FOR INDIRECT LATENT HEAT STORAGE CONTAINERS AND SYSTEMS}

The integration of latent heat storage containers into specific heating or cooling networks can be divided by the heat transfer fluid used: air or liquid. Using water as the heat transfer fluid, latent heat storage containers and systems could be integrated with conventional domestic central heating systems using water radiators, ideal to retrofit when changing a gas boiler for a heat pump [83], as illustrated in Figure 4 A. Using air as the heat transfer fluid, latent heat storage containers and systems can be integrated into centralized ventilation systems, typical in large office areas and commercial buildings, as illustrated in Figure 4 B. 

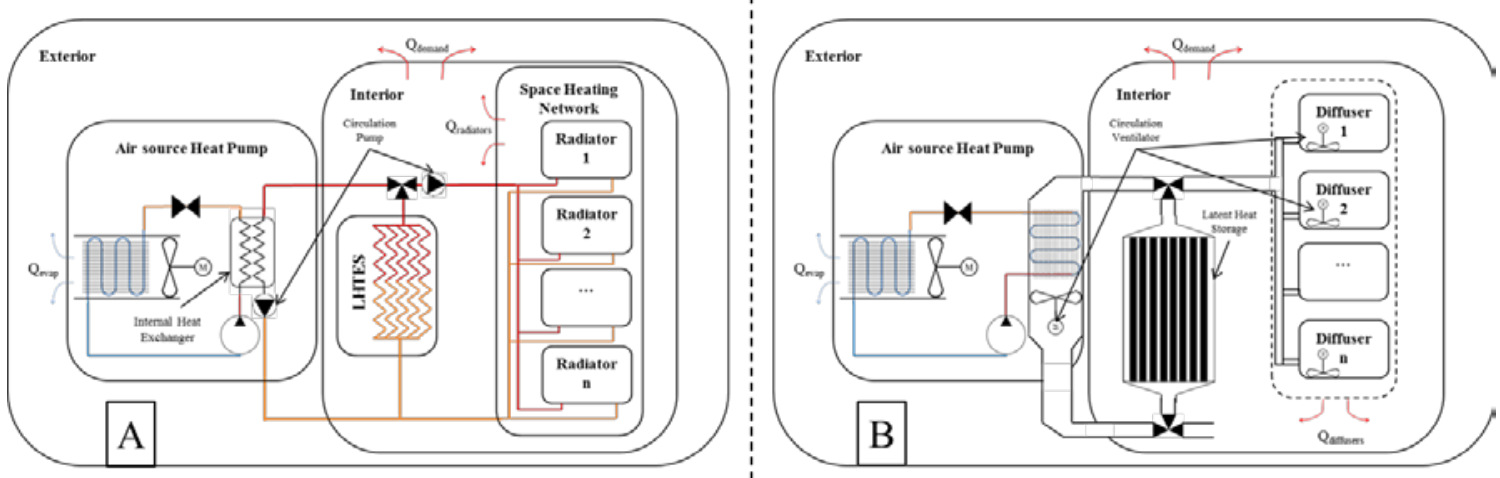

Figure 4 - Simplified diagrams of the integration of LHTES into water space heating systems (A) and centralized air space heating systems (B).

Most latent heat storage containers can be divided into two groups: compact and encapsulated. In compact systems, the PCM is in enclosed within a large container with an embedded heat exchanger [84], a general configuration used is the shell and tube type, presented in Figure 5 A. Compact latent heat storage systems are generally designed to integrate with water heating systems [18], [85]. Encapsulated systems are those in which the PCM is contained within small containers, over which the heat transfer fluid flows, leading to a heat storage system that contains a greater component of sensible heat storage than compact latent heat storage systems over the same temperature range [86]. Such encapsulated designs have the versatility to be integrated with both air and water heating networks, due to their shape versatility and leak proof construction. Figure 5 presents cross sections of a selection of 3 different types of latent heat storage containers suitable to be integrated with the heating networks described in Figure 4. A void fraction needs to be included in the PCM storage container to allow for thermal expansion that occurs during the melt process.

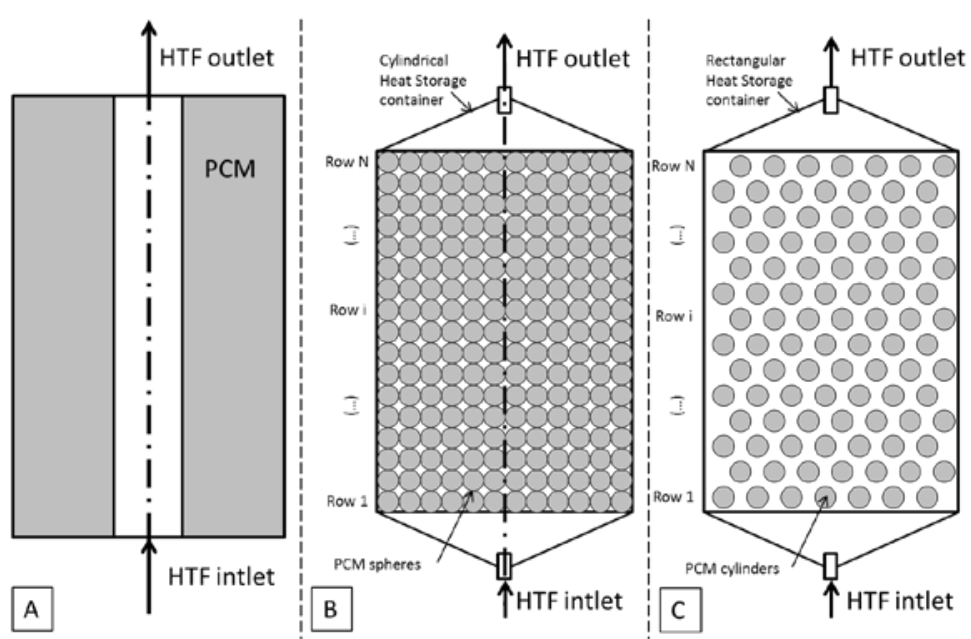

Figure 5 - Cross sections of a compact tube in tube (A), a encapsulated packed bed (B) and encapsulated staggered cylinders $(\mathrm{C})$ latent heat storage containers.

\section{i. Compact Latent Heat StORAge Systems}

Compact latent heat storage systems can have much higher PCM volumetric ratios $\left[\mathrm{m}^{3}{ }_{\mathrm{PCM}} / \mathrm{m}^{3}{ }_{\mathrm{Container}}\right]$ than encapsulated latent heat systems, providing in theory longer duration isothermal outputs; however, low rates of thermal diffusion within the bulk PCM can be a major challenge, leading to lower rates of heat output than can be achieved with encapsulated systems. 
For domestic and small district water heating requirements, characterized by heating rates tipically below $20 \mathrm{~kW}$, more complex heat exchanger configurations can be used to obtain higher inlet-outlet temperature differentials, since flow head losses are not the main challenge. Figure 6 presents a schematic diagram of a 18770 L PCM container modelled by Nakaso et al. [18], with a predicted thermal storage capacity using a paraffin wax with a melting temperature of $49^{\circ} \mathrm{C}$ (discharged from $53^{\circ} \mathrm{C}$ to $40^{\circ} \mathrm{C}$ ) of $516.7 \mathrm{kWh}_{\mathrm{th}}$. He predicted numerically that without any thermal enhancement, the system could provide a constant $25 \mathrm{~kW}$ thermal power output for $80 \%$ of its total capacity, around $16 \mathrm{~h}$ and 32 minutes.

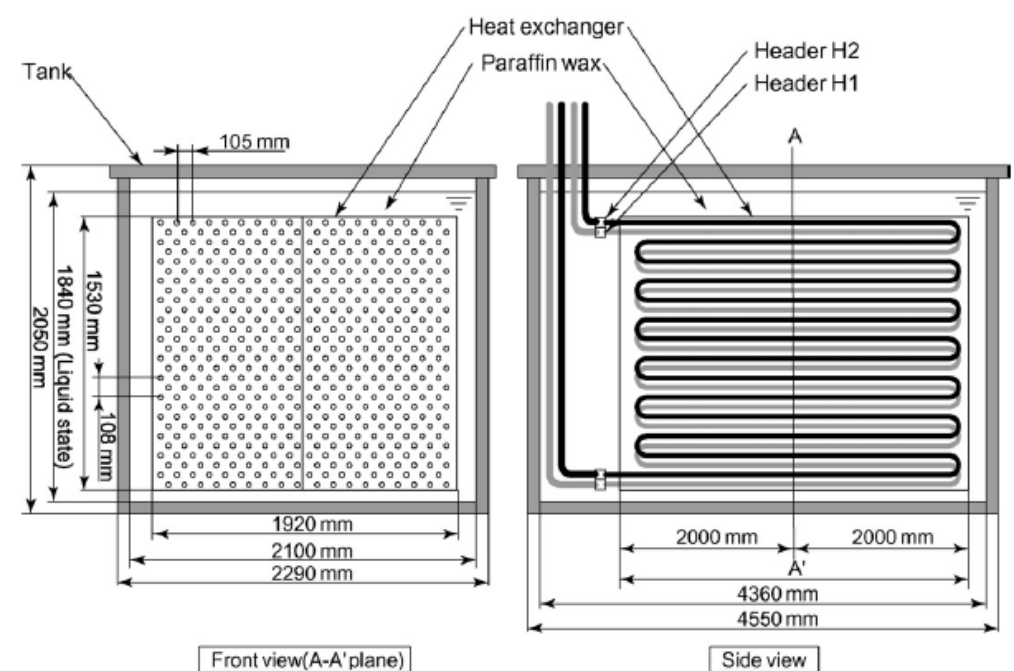

Figure 6 -A schematic diagram of the 18 770L compact latent heat storage unit designed by Nakaso et al. [18], comprised of 18 parallel $28 \mathrm{~mm}$ copper tubes, each having 14 passes through the PCM volume.

For large process heating requirements, large parallel arrays of tubes should be used, to overcome the heat transfer limitation imposed by the PCMs low thermal conductivity [12], rather than using complex heat exchanging geometries [18]. This enables the heat transfer path length to be reduced, higher power outputs achieved, reduced heat transfer fluid volume flow rate, and lower frictional head losses. Figure 7 A, illustrates the cross section of a rectangular cross section container with 100 tubes running in parallel for the heat transfer fluid. The proposed system could contain up to $827 \mathrm{~L}$ of PCM within a container $2 \mathrm{~m}$ high with a square cross section of $800 \mathrm{~mm} \times 800 \mathrm{~mm}$.
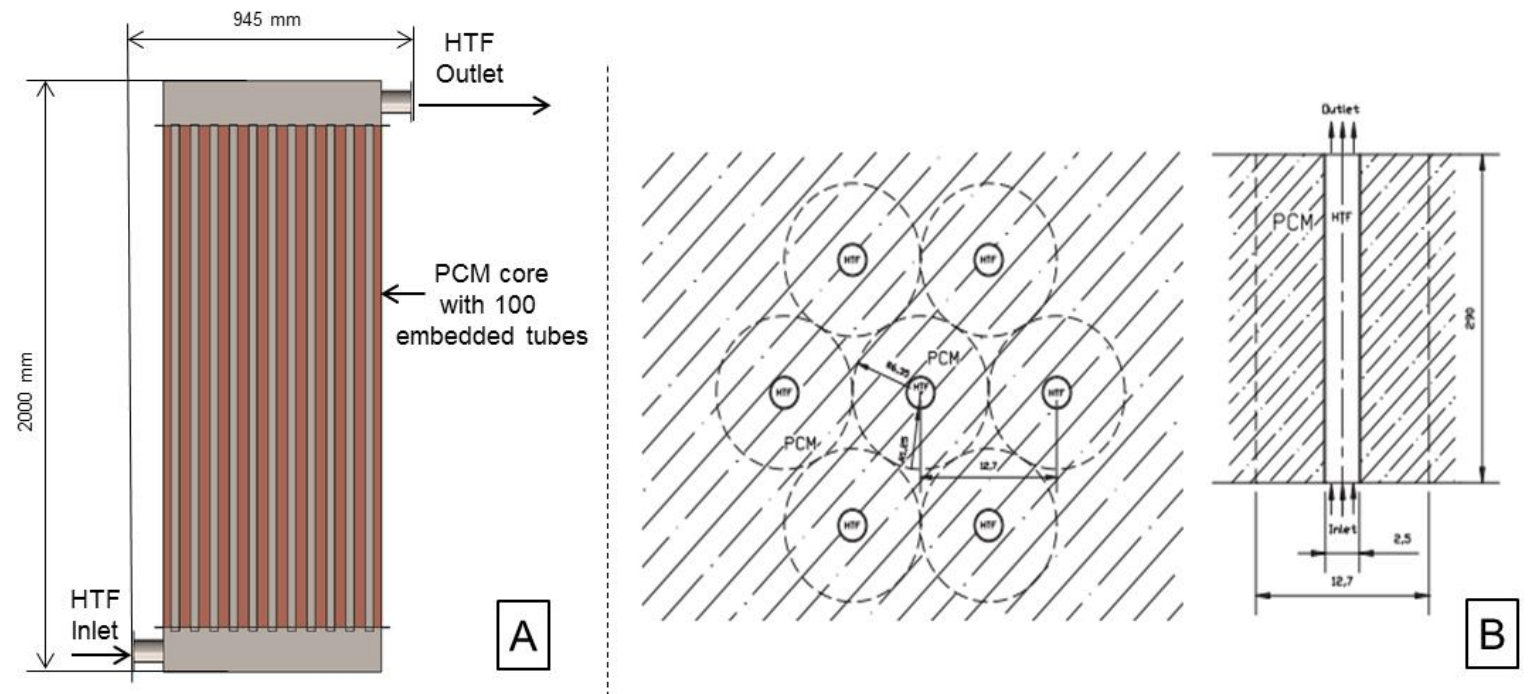

Figure 7 - Proposed design for a 827L compact latent heat storage container for process heating applications (A), and the geometrical arrangement and tube spacing (B), studied by Collela et al. [12]. 
249 Latent heat storage for use with district heating networks has been studied by Colella et al. [12], and compared to hot water storage which is commonly used in many district heating systems. Due to the high energy density of latent heat storage systems, portable containers charged from industrial waste heat streams could be of potential interest in providing heat to the nearby district heating networks. Figure 8 presents the design of a prototype thermal storage system for use with a district heating system housed in a 20 foot long cargo container tested by Deckert et al. [87]; the system can store a maximum capacity of $1758 \mathrm{kWh}_{\text {th }}$, using sodium acetate trihydrate between 90 and $25^{\circ} \mathrm{C}$; being the heat supplied by a biogas plant located $6 \mathrm{~km}$ from the district heat network with the charged store being physically transported between locations. Limiting the practical storage capacity to $80 \%$, the compact latent heat storage system could provide $40 \mathrm{~kW}$ of nearly constant thermal output over a discharge time of $38 \mathrm{~h}$.

Figure 8 - Structure of the prototype storage system developed by Deckert et al. [87] to meet the heat demands of a district heating network.

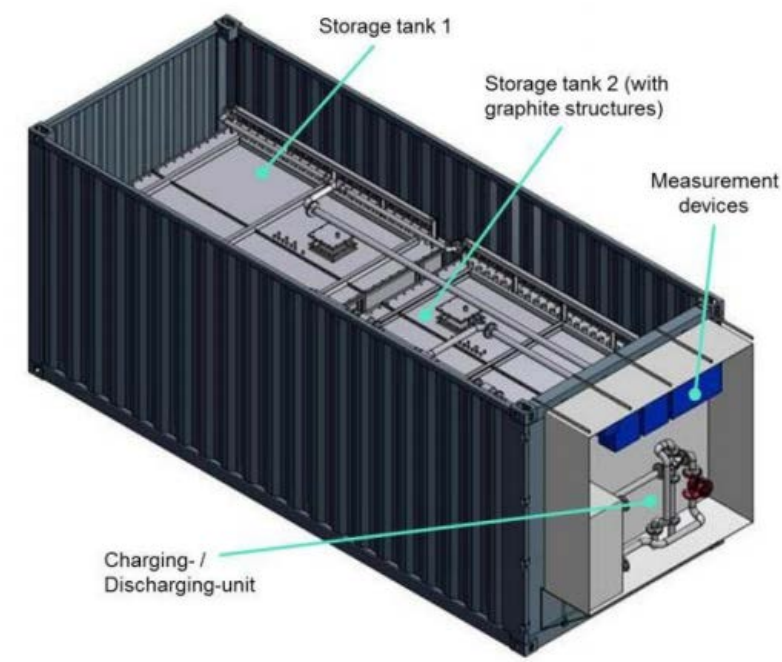

Systems using encapsulated PCMs offer higher heat transfer area per system volume $\left[\mathrm{m}^{2}{ }_{\text {HT ar- }}\right.$ ${ }_{\mathrm{ea}} / \mathrm{m}^{3}$ System], but have lower volumetric ratios $\left[\mathrm{m}_{\mathrm{PCM}}^{3} / \mathrm{m}^{3}{ }_{\text {Sytem }}\right]$. Another advantage is the ease of obtaining leak-proof solutions [9], proving suitable for less stable materials. The ability to be used with any given storage container provides great versatility, regardless of size; hence their popularity [86], [88].

The geometries used vary significantly with the application, but they commonly have cylindrical or spherically shaped capsules, which can be inserted into off the shelf storage containers. Cabeza et al. [89], undertook a study in which two to six small cylinders containing a mixture of $90 \%$ sodium acetate trihydrate $+10 \%$ graphite as the PCM were inserted in the upper part of a domestic hot water tank, making good use of the tank's thermal stratification, Figure 9 . The study concluded that, by adding $2 \%$ by volume of PCM ( 2 tubes) to the top region of the store, they could achieve an increase of $40 \%$ in the thermal storage capacity; comparing to the common water tank over a temperature difference of $1 \mathrm{~K}$ where the PCM solidifies (around $54^{\circ} \mathrm{C}$ ). 


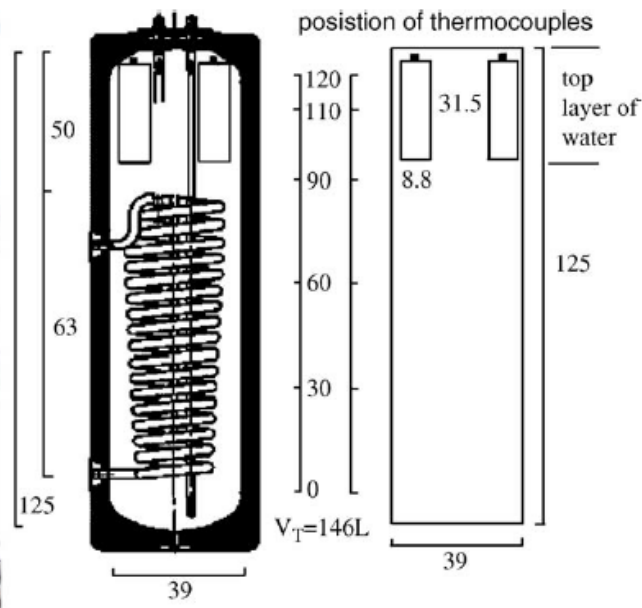

Figure 9 - Schematic representation illustrating the location of the encapsulated PCM modules inside the water tank of the experimental work undertaken by Cabeza et al. [89];

Encapsulating a PCM into spherical capsules, Figure 10, provides closer packing within the storage system [90]. This approach benefits from higher mixing of the heat transfer fluid and consequently better convective heat transfer coefficients [86] than in the vertical cylinders illustrated in Figure 9. However, lower rates of thermal diffusion within the spherical capsules can reduce their effectiveness in exchanging heat to and from the heat transfer fluid [91].

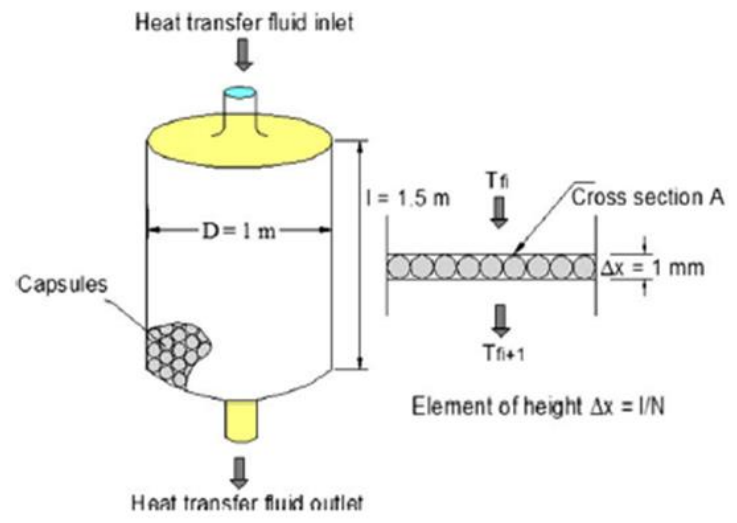

\section{A}

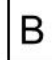

Figure 10 - Simplified drawing of the modelled container (A) and cross section view of a nodule (B) of the packed bed model used by Regin et al. [91].

Direct space cooling applications in which the charging of the store occurs during the night and discharge occurs during the day to cool office areas have been studied by Mosaffa et al. [92] and Jiao et al. [93]. Air was used as the heat transfer fluid with the PCM encapsulated in rectangular cross section slabs with $\mathrm{CaCl}_{2} \cdot 6 \mathrm{H}_{2} \mathrm{O}$ as PCM. Figure 11 illustrates s the modelled system studied by Mosaffa et al. [92] with a PCM store in an office air duct. The storage unit was composed by 80 rectangular slabs with $10 \mathrm{~mm}$ thickness, $500 \mathrm{~mm}$ width and $1.3 \mathrm{~m}$ length, with air gaps of $3.2 \mathrm{~mm}$ thickness. The modelling results demonstrated that the system could provide a constant heat output rate between 5 and 3 $\mathrm{kW}$, with the air flow varying rate from 1600 to $800 \mathrm{~m}^{3} / \mathrm{h}$ respectively; for an inlet air temperature of $36{ }^{\circ} \mathrm{C}$, the system's predicted coefficient of performance was around 7 . 


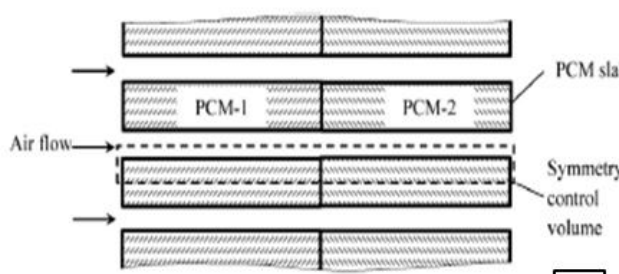

A

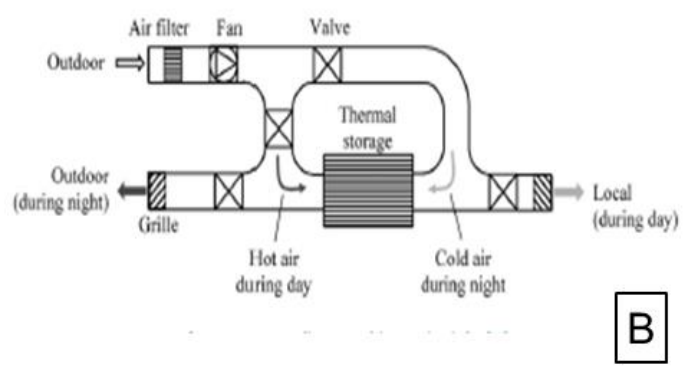

Figure 11 - Detailed view of the heat transfer arrangement inside the PCM module (A) and schematic representation of the container integration into the ventilation system studied by Mosaffa et al. [92].

Another possible application for an encapsulated latent heat storage system was studied in [94] and is illustrated in figure 12. . Heat from solar thermal collectors is stored in an array of cylinders filled with paraffin wax, , air is used as the heat transfer fluid.. Due to the poor convective heat transfer obtained to the outer shell of the capsules, aluminium strips were used to increase the effective heat transfer area of the cylinders, providing a substantial increase in the latent heat storage system's effectiveness and the global solar collector system efficiency.

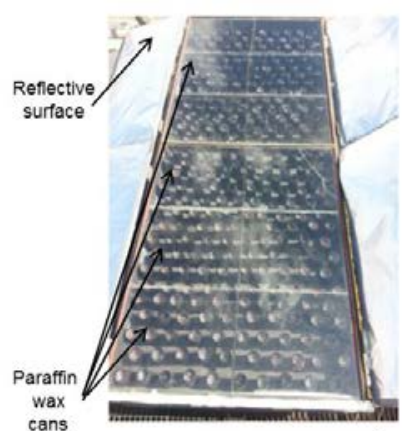

A

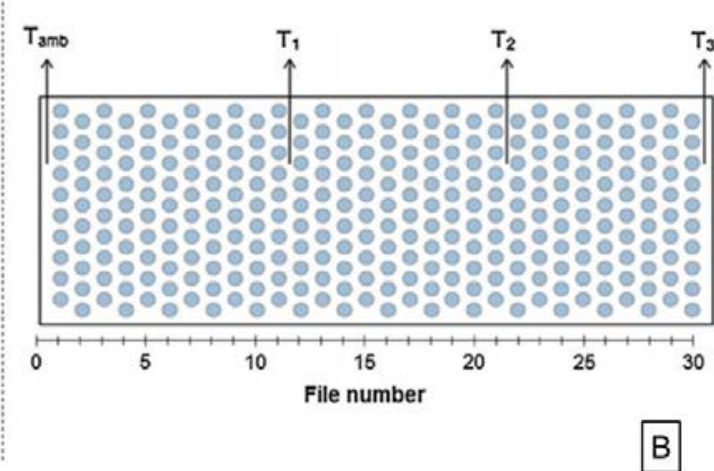

Figure 12 - Picture of the solar air absorber (A) and schematic diagram of the absorber presenting the thermocouple positions for the experimental work performed by Reyes et al. [94].

\section{a. MiCRO ENCAPSULATION OF PCM}

Micro capsules with a diameter varying from around 1-1000 $\mu \mathrm{m}$ [32] have been used to encapsulate PCMs , such micro capsules when introduced into a liquid, form a slurry, effectively increasing the thermal storage capacity of the working fluid and potentially its convective heat transfer properties. Current production methods for micro encapsulated PCMs are: coacervation, suspension and emulsion polymerization, poly-condensation and polyadition. Huang et al. [21], undertook a study in which a cylindrical container filled with a PCM slurry was heated and cooled using a helical coil heat exchanger. The slurry varied between 25,35 and $50 \%$ composition by volume of PCM capsules to carrier fluid. It was concluded that higher volumetric ratios (50\% respectively) reduced natural convection heat transfer within the storage container. Another characteristic of using PCM filled microcapsules was the low PCM volumetric ratios per capsule, normally around 50\%, which when multiplied by the slurry volumetric ratio leads to a very low PCM volumetric ratio which reduces the typical heat capacity increase obtained when using PCMs.

\section{ii. HEAT TRANSFER ENHANCEMENT METHODS}


Most PCMs have low thermal conductivity, which can seriously affect the storage system charge and discharge rates. To address this limitation, extended metal surfaces [84], conductive powders [17] or conductive matrices [18] have proven to be effective in increasing the PCMs heat transport properties, leading to a more uniform temperature within the PCM and better charge and discharge effectiveness for the latent heat storage container/system.

\section{a. EXTENDED METAL SURFACES}

One of the most widely used heat transfer enhancement techniques used is to increase the heat transfer area by adding extended metal surfaces, fins. Various studies have been made on modelling the phase change process with different fin geometries [95], [96]. A study made by Agyenim et al. [9], tested a compact horizontal tube in tube container using erythritol as the PCM, using axial fins to enhance heat transfer. They found for this system melting/solidifying properties that would provide a suitable a heat source for driving an absorption cooling system. Figure 13 illustrates two common fin geometries widely used in the literature [17].

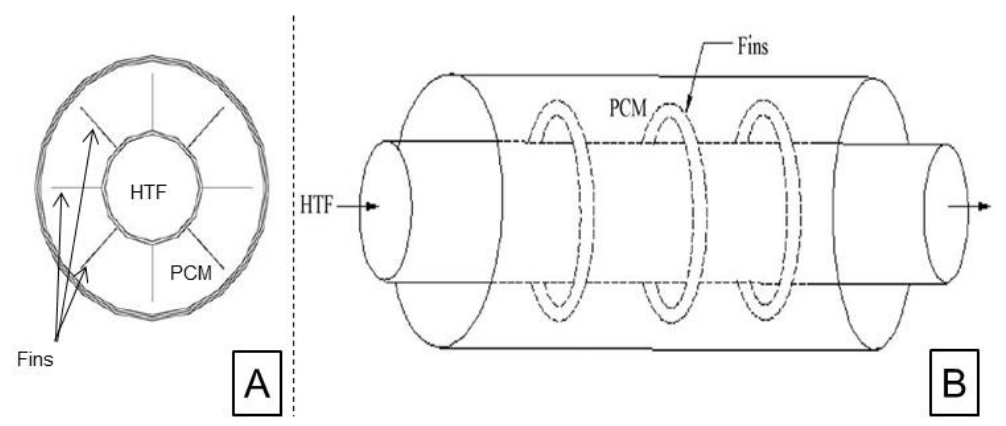

Figure 13 - Cross section of a tube in tube heat storage unit with longitudinal fins from Agyenim et al. [9], and a schematic representation of a tube in tube heat storage unit with annular fins from Jegadeeswaran et al. [17].

\section{b. HEAT TRANSFER ENHANCEMENT USING CARBON}

Exfoliated graphite, also known as expanded graphite (EG), with a thermal conductivity ranging from 24 to $470 \mathrm{~W} / \mathrm{m} . \mathrm{K}$, has the potential to increase the global PCM thermal conductivity [17], with low volume ratios (usually around 10-15\% [32]). EG is generally obtained from the oxidation of natural graphite with a mixture of nitric and sulphuric acid, followed by drying in an oven and rapid heating in a furnace at 800 to $900^{\circ} \mathrm{C}$ to obtain rapid expansion. The PCM is impregnated into the EG under vacuum, this prevents the formation of air gaps within the EG/PCM composite [17], [43]. This technique is the most effective procedure currently used to enhance the PCM thermal conductivity [97]. It also provides a shape-stabilized (SS) form to the PCM since the pore cavities can withstand the thermal expansion typical during phase change and prevent leakage of molten PCM [43]. 

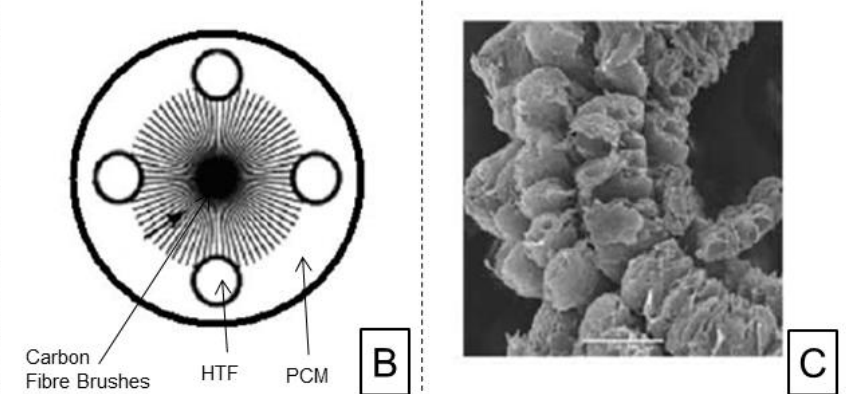

Figure 14 -Cross-section diagram of a carbon fibre cloth (A), a carbon fibre brush (B) and EG viewed with a SEM microscope Jegadeeswaran et al. [17].

370

The container studied by Nakaso et al. [18] presented in Figure 6 was predicted to double its heat output (from 25 to $50 \mathrm{~kW}_{\text {th }}$ ) if a carbon fibre cloth of $0.8 \% \mathrm{v} / \mathrm{v}$ was incorpoarted into the system. The system would then provide a nearly constant heat output of 50kW for around $10 \mathrm{~h}$ and 20 minutes.

\section{c. THERMAL CONDUCTIVITY ENHANCEMENT USING METAL MATRICES}

Using sparse metal matrices is another effective way to increase thermal conductivity within a PCM container, structure that would also provide multiple nucleation points. Steel wool is a more feasible method of improving thermal conductivity of a PCM, compared to expandable graphite, but does not provide a shape stabilized solution; since it is not as compactable as graphite. Figure 15 presents 2 approaches used to effectively enhance heat transfer within a PCM.

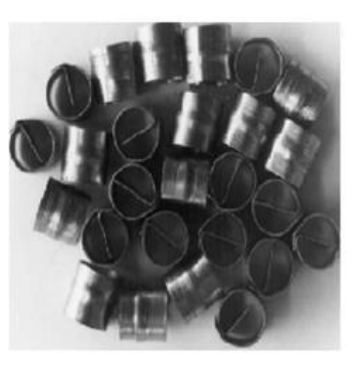

A

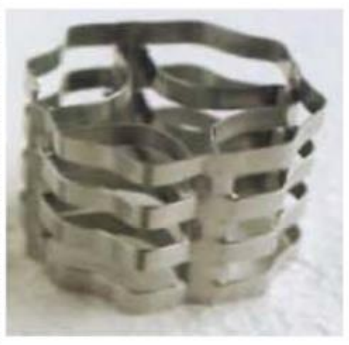

B

Figure 15 - Stainless steel (A) and aluminium lessing rings (B) from Agyenim et al. [9].

\section{d. USING CONDUCTIVE POWDERS}

Including small percentages by volume of metallic particles (aluminium, copper, silver, nickel), or graphite [17] can also increase thermal diffusion within low thermal conductivity PCMs. It would also have the added benefit of increasing the number of potential nucleation points, potentially enhancing crystallization within the PCM. However, the conductive material could lose its miscibility when the PCM is in the molten state (due to differences in density), separating from the storage material and sinking to the base of the container. This could be prevented by including gelling agents in the PCM [43], with a consequent reduction in the PCM volume ratio.

\section{e. DIRECT HEAT TRANSFER TECHNIQUES}


Another technique to increase the heat transfer would be to provide direct contact between the heat transfer fluid and the PCM. This would provide an effective increase in heat transfer during the melting process since the convective nature of the heat transfer fluid would act directly on the solid PCM phase [20]. Weilong et al. [22] studied the performance of a direct contact latent heat storage container using erythritol and an heat transfer oil, Figure 16; and it concluded that at the beginning of the melt process the oil has a low flow rate due to the block of solid erythritol, the top surface of the PCM melts faster than the bottom due to the higher heat transfer rate and the melting time varies sig-

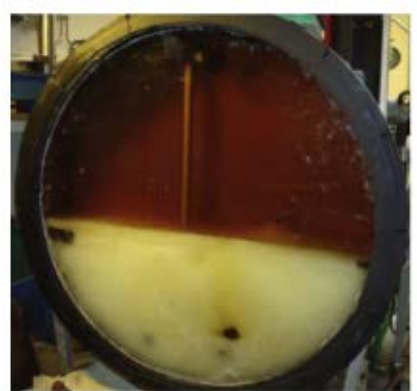

(a) initial stage

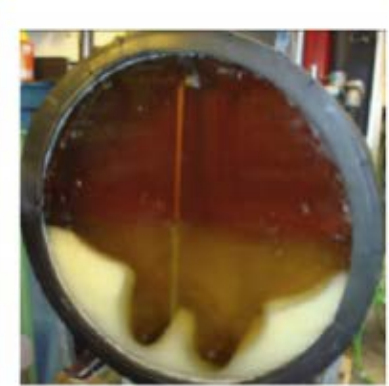

(b) middle stage

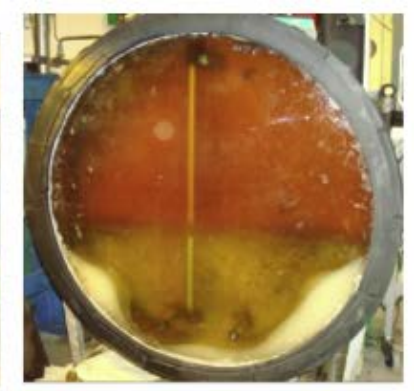

(c) final stage

Figure 16 - Temporal variation of the melting process in a direct contact heat transfer container using erythritol as the PCM and oil as the heat transfer fluid, from Weilong et al. [20].

To overcome the initial blocking of the fluid flow path when the PCM is in the solid state, Shaopeng et al. [23] studied the insertion of electric heaters, Figure 17, and concluded that the overall energy 415 spent on melting the initial flow pathways was $5 \%$ of the total thermal energy stored.

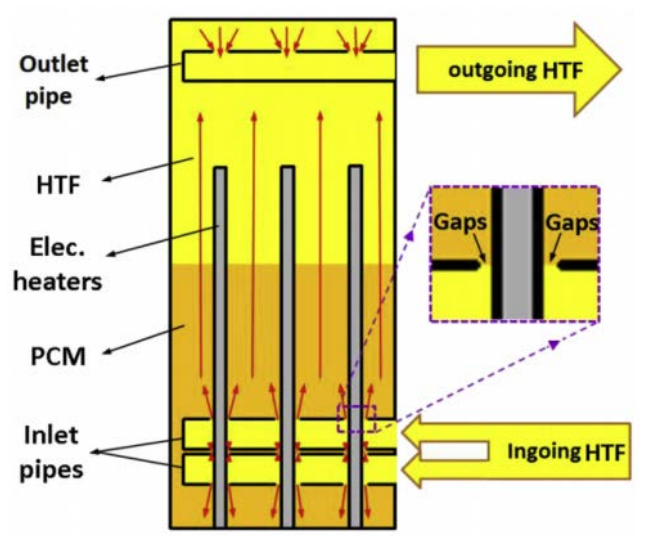

Figure 17 - Schematic cross section showing the locations of the electric heaters in the inlet pipes, studied by Shaopeng et al. [23].

\section{CONCLUSIONS}

Phase change materials have the potential to store large amounts of energy within a smaller temperature range when compared to common sensible heat storage materials. Due to the low thermal conductivities of many PCMs, poor rates of thermal diffusion within the PCM can seriously affect the storage system charge and discharge rates that can be achieved. 
A comprehensive review of PCMs melting between 0 and $250^{\circ} \mathrm{C}$ has been made and the thermophysical properties of the materials having the most appropriate properties presented. Below $100{ }^{\circ} \mathrm{C}$, organic compounds and salt hydrates are the most interesting materials. Eutectic mixtures with Urea seem promising around $100{ }^{\circ} \mathrm{C}$, and in the range from $130^{\circ} \mathrm{C}$ up to $1250^{\circ} \mathrm{C}$ eutectic mixtures of inorganic salts appear the most promising PCMs. A mixture of sodium and potassium fomates melting around $170{ }^{\circ} \mathrm{C}$ appears attractive due to is relatively low price and moderate latent heat of fusion.

A review of potential indirect latent heat storage containers and systems suitable for integration with various process heating and cooling networks is also reported. Due to its geometrical versatility, encapsulated systems seem more feasible since they can be integrated to any existing system without major technical constrains, although they have lower PCM volume ratios. Compact systems offer larger isothermal stages due to their higher PCM volume ratios; however, heat transfer enhancement among the PCM is imperative to achieve reasonable thermal power output rates, since PCMs thermal conductivity can be a major issue.

\section{Acknowledgements}

The research presented in this paper is funded by the EPSRC through Grant reference EP/K011847/1, Interdisciplinary centre for Storage, Transformation and Upgrading of Thermal Energy (i-STUT)E and a Loughborough University funded PhD studentship.

\section{REFERENCES}

[1] International Energy Agency, "World Energy Outlook 2013,” 2015.

[2] K. Harris, A. Annut, and I. MacLeay, Digest of United Kingdom Energy Statistics 2015, vol. b.

[3] A. D. Hawkes, "Long-run marginal CO2 emissions factors in national electricity systems,"

[4] A. D. Hawkes, "Estimating marginal CO2 emissions rates for national electricity systems," Energy Policy, vol. 38, no. 10, pp. 5977-5987, Oct. 2010.

[5] National Grid, “UK Future Energy Scenarios 2014,” Energy, no. July, p. 220, 2014.

[6] D. Haillot, E. Franquet, S. Gibout, and J.-P. Bédécarrats, "Optimization of solar DHW system including PCM media,” Appl. Energy, vol. 109, pp. 470-475, Sep. 2013. including a PCM module,” Appl. Therm. Eng., vol. 26, pp. 1328-1333, 2006. heat storage with open reactor system,” Appl. Energy, vol. 109, pp. 360-365, Sep. 2013. 
[10] A. Gil, E. Oró, G. Peiró, S. Álvarez, and L. F. Cabeza, "Material selection and testing for thermal energy storage in solar cooling,” Renew. Energy, vol. 57, pp. 366-371, 2013.

[11] A. Gil, C. Barreneche, P. Moreno, C. Solé, A. Inés Fernández, and L. F. Cabeza, “Thermal behaviour of d-mannitol when used as PCM: Comparison of results obtained by DSC and in a thermal energy storage unit at pilot plant scale,” Appl. Energy, vol. 111, pp. 1107-1113, Nov. 2013.

[12] F. Colella, A. Sciacovelli, and V. Verda, "Numerical analysis of a medium scale latent energy storage unit for district heating systems,” Energy, vol. 45, no. 1, pp. 397-406, Sep. 2012.

[13] J. Kensby, A. Trüschel, and J.-O. Dalenbäck, "Potential of residential buildings as thermal energy storage in district heating systems - Results from a pilot test,” Appl. Energy, vol. 137, pp. 773-781, Jan. 2015.

[14] J. Vivian, G. Manente, and A. Lazzaretto, "A general framework to select working fluid and configuration of ORCs for low-to-medium temperature heat sources,” Appl. Energy, vol. 156, pp. 727-746, Oct. 2015.

[15] A. R. Higgo and T. J. Zhang, "Characterization of a Compact Organic Rankine Cycle Prototype for Low-grade Transient Solar Energy Conversion,” Energy Procedia, vol. 69, pp. 1113-1122, May 2015.

[16] S. Kalogirou, “The potential of solar industrial process heat applications,” Appl. Energy, vol. 76, no. 4, pp. 337-361, Dec. 2003.

[17] S. Jegadheeswaran and S. D. Pohekar, "Performance enhancement in latent heat thermal storage system: A review,” Renew. Sustain. Energy Rev., vol. 13, no. 9, pp. 2225-2244, 2009.

[18] K. Nakaso, H. Teshima, A. Yoshimura, S. Nogami, Y. Hamada, and J. Fukai, "Extension of heat transfer area using carbon fiber cloths in latent heat thermal energy storage tanks," Chem. Eng. Process. Process Intensif., vol. 47, no. 5, pp. 879-885, 2008.

[19] G. Q. Qi, C. L. Liang, R. Y. Bao, Z. Y. Liu, W. Yang, B. H. Xie, and M. B. Yang, "Polyethylene glycol based shape-stabilized phase change material for thermal energy storage with ultra-low content of graphene oxide,” Sol. Energy Mater. Sol. Cells, vol. 123, pp. 171177, 2014.

[20] W. Wang, X. Yang, Y. Fang, J. Ding, and J. Yan, "Preparation and thermal properties of polyethylene glycol/expanded graphite blends for energy storage,” Appl. Energy, vol. 86, no. 9, pp. 1479-1483, 2009.

[21] M. J. Huang, P. C. Eames, S. McCormack, P. Griffiths, and N. J. Hewitt, "Microencapsulated phase change slurries for thermal energy storage in a residential solar energy system," Renew. Energy, vol. 36, pp. 2932-2939, 2011.

[22] W. Wang, S. He, S. Guo, J. Yan, and J. Ding, “A combined experimental and simulation study on charging process of Erythritol-HTO direct-blending based energy storage system,” Energy Convers. Manag., vol. 83, pp. 306-313, Jul. 2014.

[23] S. Guo, J. Zhao, W. Wang, G. Jin, X. Wang, Q. An, and W. Gao, "Experimental study on solving the blocking for the direct contact mobilized thermal energy storage container," Appl. Therm. Eng., vol. 78, pp. 556-564, Mar. 2015. 
[25] a. Raemy and T. F. Schweizer, "Thermal behaviour of carbohydrates studied by heat flow calorimetry,” J. Therm. Anal., vol. 28, pp. 95-108, 1983.

[26] H. Schiweck, A. Bär, R. Vogel, E. Schwarz, M. Kunz, C. Dusautois, A. Clement, C. Lefranc, B. Lüssem, M. Moser, and S. Peters, "Sugar Alcohols," in Ullmann's Encylcopedia of Industrial Chemistry, Wiley-VCH Verlag GmbH \& Co. KGaA, 2012, pp. 2-32.

[27] B. Cornils and P. Lappe, "Dicarboxylic acids. Aliphatic," in Ullmann's Encyclopedia of Industrial Chemistry, Wiley-VCH Verlag GmbH \& Co. KGaA, 2008.

[28] D. H. Kerridge, "The chemistry of molten acetamide and acetamide complexes," Chem. Soc. Rev., vol. 17, p. 181, 1988.

[29] M. M. Kenisarin, "Thermophysical properties of some organic phase change materials for latent heat storage. A review,” Sol. Energy, vol. 107, pp. 553-575, 2014.

[30] I. Mavrovic, a. R. Shirley, and G. R. Coleman, “Urea,” Kirk-Othmer Encycl. Chem. Technol., vol. 2, pp. 1-21, 2010.

[31] D. Haillot, T. Bauer, U. Kröner, and R. Tamme, "Thermal analysis of phase change materials in the temperature range 120-150 ${ }^{\circ} \mathrm{c}$,” Thermochim. Acta, vol. 513, no. 1-2, pp. 49-59, 2011.

[32] N. R. Jankowski and F. P. McCluskey, "A review of phase change materials for vehicle component thermal buffering,” Appl. Energy, vol. 113, pp. 1525-1561, 2014.

[33] A. P. Miller, “Lange’s Handbook of Chemistry,” Am. J. Public Heal. Nations Heal., vol. 31, no. 12, p. 1324, 1941.

[34] S. Harish, D. Orejon, Y. Takata, and M. Kohno, "Thermal conductivity enhancement of lauric acid phase change nanocomposite with graphene nanoplatelets,” Appl. Therm. Eng., vol. 80, pp. 205-211, Apr. 2015.

[35] Y. Yuan, N. Zhang, W. Tao, X. Cao, and Y. He, "Fatty acids as phase change materials: A review,” Renewable and Sustainable Energy Reviews, vol. 29. pp. 482-498, 2014.

[36] F. Tang, L. Cao, and G. Fang, "Preparation and thermal properties of stearic acid/titanium dioxide composites as shape-stabilized phase change materials for building thermal energy storage,” Energy Build., vol. 80, pp. 352-357, Sep. 2014.

[37] M. M. Farid, A. M. Khudhair, S. A. K. Razack, and S. Al-Hallaj, “A review on phase change energy storage: Materials and applications,” Energy Convers. Manag., vol. 45, pp. 1597-1615, 2004.

[38] M. Silakhori, H. Fauzi, M. R. Mahmoudian, H. S. C. Metselaar, T. M. I. Mahlia, and H. M. Khanlou, "Preparation and thermal properties of form-stable phase change materials composed of palmitic acid/polypyrrole/graphene nanoplatelets,” Energy Build., vol. 99, pp. 189-195, Jul. 2015.

[39] “Website of Rubitherm GmbH,” Rubitherm GmbH, 2016. [Online]. Available: http://www.rubitherm.eu/. 
[40] J. G. Dunn, H. G. Smith, and R. L. Willix, “The supercooling of acetamide,” Thermochim. Acta, vol. 80, no. 2, pp. 343-353, Oct. 1984.

[41] W. Riemensschneider and M. Tanifuji, “Oxalic Acid,” in Ullmann's Encyclopedia of Industrial Chemistry, 25th ed., Wiley-VCH Verlag GmbH \& Co. KGaA, 2012, pp. 543-600.

[42] B. Tong, Z. C. Tan, J. N. Zhang, and S. X. Wang, "Thermodynamic investigation of several natural polyols (III): Heat capacities and thermodynamic properties of erythritol," J. Therm. Anal. Calorim., vol. 95, no. 2, pp. 469-475, 2009.

[43] K. Pielichowska and K. Pielichowski, "Phase change materials for thermal energy storage," Prog. Mater. Sci., vol. 65, pp. 67-123, 2014.

[44] P. Lorz, F. Towae, W. Enke, R. Jäckh, N. Bhargava, and W. Hillesheim, "Phthalic acid and Derivates," in Ullmann's Encyclopedia of Industrial Chemistry, Wiley-VCH Verlag GmbH \& Co. KGaA, 2012, pp. 35-154.

[45] K. Muraishi and Y. Suzuki, "The thermal behaviour of dicarboxylic acids in various atmospheres,” Thermochim. Acta, vol. 232, pp. 195-203, 1994.

[46] K. Lohbeck, H. Haferkorn, W. Fuhrmann, and N. Fedtke, "Maleic and Fumaric Acids," in Ullmann's Encyclopedia of Industrial Chemistry, Wiley-VCH Verlag GmbH \& Co. KGaA, 2005, pp. 413-454.

[47] T. Felthouse, J. Burnett, B. Horrell, M. Mommey, and Y.-J. Kuo, "Maleic Anhydride, Maleic Acid , and Fumaric Acid," in Kirk-Othmer Encyclopedia of Industrial Chemistry, no. 10, John Wiley \& Sons, Inc., 1933.

[48] T. Maki and K. Takeda, “Benzoic Acid and Derivatives,” in Ullmann's Encyclopedia of Industrial Chemistry, vol. 60, 2012, pp. 329-342.

[49] T. Hasl and I. Jiricek, "The prediction of heat storage properties by the study of structural effect on organic phase change materials,” Energy Procedia, vol. 46, pp. 301-309, 2014.

[50] G. Barone, G. Della Gatta, D. Ferro, and V. Piacente, "Enthalpies and entropies of sublimation, vaporization and fusion of nine polyhydric alcohols,” J. Chem. Soc. Faraday Trans., vol. 86, no. 1, p. 75, 1990.

[51] A. Solé, H. Neumann, S. Niedermaier, I. Martorell, P. Schossig, and L. F. Cabeza, "Stability of sugar alcohols as PCM for thermal energy storage,” Sol. Energy Mater. Sol. Cells, vol. 126, pp. 125-134, 2014.

[52] G. Krishna Bama, R. Anitha, and K. Ramachandran, "On the thermal properties of aqueous solution of D-mannitol,” Nondestruct. Test. Eval., vol. 25, no. 1, pp. 67-75, Oct. 2009.

[53] A. Gil, E. Oró, L. Miró, G. Peiró, Á. Ruiz, J. M. Salmerón, and L. F. Cabeza, "Experimental analysis of hydroquinone used as phase change material (PCM) to be applied in solar cooling refrigeration,” Int. J. Refrig., vol. 39, pp. 95-103, Mar. 2014.

[54] G. a. Lane, "Phase change materials for energy storage nucleation to prevent supercooling," Sol. Energy Mater. Sol. Cells, vol. 27, pp. 135-160, 1992. 
[55] G. M. Habashy and G. A. Kolta, "Thermal decomposition of the hydrates of barium hydroxide," J. Inorg. Nucl. Chem., vol. 34, no. 1961, pp. 57-67, 1972.

[56] F. C. Porisini, "Salt hydrates used for latent heat storage: Corrosion of metals and reliability of thermal performance,” Sol. Energy, vol. 41, no. 2, pp. 193-197, 1988.

[57] W. E. Acree, "Thermodynamic properties of organic compounds: enthalpy of fusion and melting point temperature compilation,” Thermochim. Acta, vol. 189, pp. 37-56, 1991.

[58] B. Zalba, "Review on thermal energy storage with phase change: materials, heat transfer analysis and applications,” Appl. Therm. Eng., vol. 23, no. 3, pp. 251-283, 2003.

[59] M. Hadjieva, R. Stoykov, and T. Filipova, "Composite salt-hydrate concrete system for building energy storage,” Renew. Energy, vol. 19, no. 1-2, pp. 111-115, Jan. 2000.

[60] B. Sandnes and J. Rekstad, "Supercooling salt hydrates: Stored enthalpy as a function of temperature,” Sol. Energy, vol. 80, no. 5, pp. 616-625, May 2006.

[61] J. B. Johansen, M. Dannemand, W. Kong, J. Fan, J. Dragsted, and S. Furbo, “Thermal Conductivity Enhancement of Sodium Acetate Trihydrate by Adding Graphite Powder and the Effect on Stability of Supercooling,” Energy Procedia, vol. 70, pp. 249-256, May 2015.

[62] P. Patnaik, Handbook of Inorganic Chemicals. McGraw-Hill, 2003.

[63] L. Zhongliang, M. Chongfang, and L. Jing, “An experimental study on the stability and reliability of the thermal properties of barium hydroxide octahydrate as a phase change material," Proc. 7th Expert Meet. Work. IEA Annex 17 Adv. Therm. Energy Storage trough Phase Chang. Mater. Chem. React. - Feasibility Stud. Demonstr. Proj., pp. 63-69, 2004.

[64] R. Pilar, L. Svoboda, P. Honcova, and L. Oravova, "Study of magnesium chloride hexahydrate as heat storage material,” Thermochim. Acta, vol. 546, pp. 81-86, 2012.

[65] T. Bauer, D. Laing, and R. Tamme, "Recent progress in alkali nitrate/nitrite developments for solar thermal power applications,” Molten Salts Chem. Technol. ..., no. June, pp. 1-10, 2011.

[66] J. C. Gomez, N. Calvet, A. K. Starace, and G. C. Glatzmaier, "Ca(NO3)2 —NaNO3 — KNO3 Molten Salt Mixtures for Direct Thermal Energy Storage Systems in Parabolic Trough Plants,” J. Sol. Energy Eng., vol. 135, no. May 2013, p. 021016, 2013.

[67] J. G. Cordaro, N. C. Rubin, and R. W. Bradshaw, "Multicomponent Molten Salt Mixtures Based on Nitrate/Nitrite Anions,” J. Sol. Energy Eng., vol. 133, no. February 2011, p. 011014, 2011.

[68] M. Yamada, M. Tago, S. Fukusako, and A. Horibe, "Melting point and supercooling characteristics of molten salt,” Thermochim. Acta, vol. 218, pp. 401-411, May 1993.

[69] J. . Rowlinson, "Molecular thermodynamics of fluid-phase equilibria,” The Journal of Chemical Thermodynamics, vol. 2, no. 1. pp. 158-159, 1970.

[70] Y. Yanping, T. Wenquan, C. Xiaoling, and B. Li, "Theoretic prediction of melting temperature and latent heat for a fatty acid eutectic mixture,” J. Chem. Eng. Data, vol. 56, no. 6, pp. 28892891, 2011. 
[71] J. Gmehling, J. Li, and M. Schiller, “A modified UNIFAC model. 2. Present parameter matrix and results for different thermodynamic properties,” Ind. Eng. Chem. Res., vol. 32, no. 1, pp. 178-193, 1993.

[72] G. Diarce, I. Gandarias, Á. Campos-Celador, A. García-Romero, and U. J. Griesser, "Eutectic mixtures of sugar alcohols for thermal energy storage in the $50-90^{\circ} \mathrm{C}$ temperature range," Sol. Energy Mater. Sol. Cells, vol. 134, pp. 215-226, Mar. 2015.

[73] A. Sharma, V. V. Tyagi, C. R. Chen, and D. Buddhi, "Review on thermal energy storage with phase change materials and applications,” Renew. Sustain. Energy Rev., vol. 13, pp. 318-345, 2009.

[74] G. Baran and A. Sari, "Phase change and heat transfer characteristics of a eutectic mixture of palmitic and stearic acids as PCM in a latent heat storage system,” Energy Convers. Manag., vol. 44, no. 20, pp. 3227-3246, Dec. 2003.

[75] R. I. Olivares and W. Edwards, "LiNO3-NaNO3-KNO3 salt for thermal energy storage: Thermal stability evaluation in different atmospheres," Thermochim. Acta, vol. 560, pp. 34-42, 2013.

[76] F. Roget, C. Favotto, and J. Rogez, "Study of the KNO3-LiNO3 and KNO3-NaNO3-LiNO3 eutectics as phase change materials for thermal storage in a low-temperature solar power plant," Sol. Energy, vol. 95, pp. 155-169, 2013.

[77] B. Y. Gamataeva, R. M. Bagomedova, and a. M. Gasanaliev, "Differentiation of the $\mathrm{Li}, \mathrm{Na}, \mathrm{K} \| \mathrm{NO} 2, \mathrm{NO} 3$ quaternary reciprocal system and phase formation in its stable partitioning tetrahedron LiNO2-NaNO2-KNO2-KNO3,” Russ. J. Inorg. Chem., vol. 59, no. 2, pp. 134-140, 2014.

[78] G. J. Janz and R. P. T. Tomkins, "Molten Salts: Volume 5, Part 2. Additional Single and Multi-Component Salt Systems. Electrical Conductance, Density, Viscosity and Surface Tension Data.” New York, 1983.

[79] A. M. Gasanaliev and B. Y. Gamataeva, "Heat-accumulating properties of melts,” Russ. Chem. Rev., vol. 69, pp. 179-186, 2007.

[80] L. Dante, B. Mario, C. Augusto, and F. Paolo, "Molten Mixtures of K, Na Formates with Alkali Halides. Note I,” Zeitschrift für Naturforschung A, vol. 25. p. 52, 1970.

[81] M. M. Kenisarin, "High-temperature phase change materials for thermal energy storage,” Renew. Sustain. Energy Rev., vol. 14, pp. 955-970, 2010.

[82] G. J. Janz and R. P. T. Tomkins, "Molten Salts: Volume 5, Part 1 Additional Single and MultiComponent Salt systems. Electrical Conductance, Density, Viscosity and Surface Tension Data.” New York, 1980.

[83] N. J. Hewitt, "Heat pumps and energy storage - The challenges of implementation,” Appl. Energy, vol. 89, no. 1, pp. 37-44, Jan. 2012.

[84] F. Agyenim, P. Eames, and M. Smyth, "Experimental study on the melting and solidification behaviour of a medium temperature phase change storage material (Erythritol) system augmented with fins to power a $\mathrm{LiBr} / \mathrm{H} 2 \mathrm{O}$ absorption cooling system,” Renew. Energy, vol. 36, no. 1, pp. 108-117, 2011. 
[85] A. Trp, "An experimental and numerical investigation of heat transfer during technical grade paraffin melting and solidification in a shell-and-tube latent thermal energy storage unit," Sol. Energy, vol. 79, no. 6, pp. 648-660, Dec. 2005.

[86] a. Barba and M. Spiga, "Discharge mode for encapsulated PCMs in storage tanks,” Sol. Energy, vol. 74, no. February, pp. 141-148, 2003.

[87] M. Deckert, R. Scholz, S. Binder, and A. Hornung, "Economic Efficiency of Mobile Latent Heat Storages,” Energy Procedia, vol. 46, pp. 171-177, 2014.

[88] M. N. a Hawlader, M. S. Uddin, and H. J. Zhu, "Encapsulated phase change materials for thermal energy storage: Experiments and simulation,” Int. J. Energy Res., vol. 26, no. January 2001, pp. 159-171, 2002.

[89] L. F. Cabeza, M. Ibanez, C. Sole, J. Roca, and M. Nogues, "Experimentation with a water tank including a PCM module,” Sol. Energy Mater. Sol. Cells, vol. 90, no. 9, pp. 1273-1282, 2006.

[90] M. Wu, C. Xu, and Y.-L. He, "Dynamic thermal performance analysis of a molten-salt packed-bed thermal energy storage system using PCM capsules,” Appl. Energy, vol. 121, pp. 184-195, May 2014.

[91] a. Felix Regin, S. C. Solanki, and J. S. Saini, "An analysis of a packed bed latent heat thermal energy storage system using PCM capsules: Numerical investigation,” Renew. Energy, vol. 34, no. 7, pp. 1765-1773, 2009.

[92] A. H. Mosaffa, L. Garousi Farshi, C. A. Infante Ferreira, and M. A. Rosen, "Energy and exergy evaluation of a multiple-PCM thermal storage unit for free cooling applications," Renew. Energy, vol. 68, pp. 452-458, Aug. 2014.

[93] F. Jiao and P. Xu, "Simulation and Feasibility Analysis of PCM Based Passive Cooling Technique in Residential House,” Procedia Eng., vol. 121, pp. 1969-1976, 2015.

[94] A. Reyes, L. Henríquez-Vargas, R. Aravena, and F. Sepúlveda, "Experimental analysis, modeling and simulation of a solar energy accumulator with paraffin wax as PCM," Energy Convers. Manag., vol. 105, pp. 189-196, Nov. 2015.

[95] J. Shon, H. Kim, and K. Lee, "Improved heat storage rate for an automobile coolant waste heat recovery system using phase-change material in a fin-tube heat exchanger,” Appl. Energy, vol. 113, pp. 680-689, Jan. 2014.

[96] A. Sciacovelli, F. Gagliardi, and V. Verda, "Maximization of performance of a PCM latent heat storage system with innovative fins,” Appl. Energy, vol. 137, pp. 707-715, Jan. 2015.

[97] K. Merlin, D. Delaunay, J. Soto, and L. Traonvouez, "Heat transfer enhancement in latent heat thermal storage systems: Comparative study of different solutions and thermal contact investigation between the exchanger and the PCM,” Appl. Energy, vol. 166, pp. 107-116, Mar. 2016. 